\title{
Isolation and Molecular Characterization of a Chilean Isolate of Zucchini yellow mosaic virus
}

\author{
H. Prieto, A. Bruna, P. Hinrichsen, and C. Muñoz, Biotechnology Laboratory, Instituto de Investigaciones Ag- \\ ropecuarias (INIA) - Centro Regional de Investigación La Platina, Santiago, Chile
}

\begin{abstract}
Prieto, H., Bruna, A., Hinrichsen, P., and Muñoz, C. 2001. Isolation and molecular characterization of a Chilean isolate of Zucchini yellow mosaic virus. Plant Dis. 85:644-648.

Zucchini yellow mosaic virus (ZYMV) was described in 1981 affecting squash, melon, and other cultivated cucurbits with severe stunting and yellowing symptoms. It was reported to be present in most countries where cucurbits are grown, and in Chile since 1995, from surveys using enzyme-linked immunosorbent assay (ELISA) but without further characterization. A potyvirus was isolated from ELISA-positive symptomatic plants. The results indicate that this virus is ZYMV based on symptoms on herbaceous indicators, immunospecific electron microscopy of the purified particle, and sequencing of 395 bases of the $3^{\prime}$ end of the coat protein gene. The virus was detected in melon, watermelon, and squash plants. In agreement with previous descriptions for ZYMV, the Chilean isolate is a flexuous filamentous particle $740 \mathrm{~nm}$ long with one main protein of approximately $36 \mathrm{kDa}$. Nucleotide sequence comparisons of the $3^{\prime}$ portion of the coat protein gene revealed a high similarity to the Connecticut and California strains.
\end{abstract}

Additional keywords: Potyviridae, ssRNA

Zucchini yellow mosaic virus (ZYMV) was described in northern Italy (18). Soon thereafter, it was identified throughout the world in cucurbit-cultivated areas, including Mediterranean countries, China, Australia, Hawaii, and the continental United States $(3,4,9,12,20,22)$.

Watermelon mosaic virus type II (WMVII) and Squash mosaic virus (SqMV) have been reported in the major cucurbitgrowing area of the central valleys of Chile on squash (Cucurbita maxima) and melon (Cucumis melo) fields $(2,23)$. These viruses have recently caused significant yield reduction of honeydew melons grown for export. Viral agents causing diseases on cucurbits confirmed by annual surveys carried out by the Plant Protection Agency (Servicio Agrícola y Ganadero, SAG) since 1996 are: Cucumber mosaic virus (CMV), Tomato spotted wilt virus (TSMV), WMVII, and ZYMV. Standard assays utilize commercially available enzyme-linked immunosorbent assay (ELISA) kits, whose antibody reactivity depends on the immunogenic differences among the epitopes present in the viral particle, which means the results could be questionable for poor or intermediate absorbance values. Molecular characterization of the viruses that

Corresponding author: H. Prieto

E-mail: hprieto@platina.inia.cl

Accession Number: Bankit359290 AF308732.

Accepted for publication 27 February 2001.

Publication no. D-2001-0413-02R

(C) 2001 The American Phytopathological Society infect cucurbits in Chile is known only for isolates of WMV-II (24). Tests on melon, squash, zucchini, and watermelon showed that other potyviruses were associated with mosaic and fruit deformation symptoms. However, these tests were conducted with a weak serological reaction to commercial polyclonal anti-ZYMV antibodies.

This work focused on characterization at the molecular level of the ZYMV, including host specificity, viral particle purification, serological behavior, and electron microscopy. Finally, cloning and sequencing of the $3^{\prime}$ end of the coat protein (CP) gene of the purified particle was used to compare this isolate with other ZYMV strains and isolates described from other areas of the world.

\section{MATERIALS AND METHODS}

Sample collection. A survey was conducted from November 1995 to March 1996, in commercial fields of Chile, from La Serena $\left(30^{\circ} \mathrm{S} 71^{\circ} \mathrm{W}\right)$ to Curicó $\left(35^{\circ} \mathrm{S}\right.$ $\left.71^{\circ} \mathrm{W}\right)$. Forty-four samples with viruslike symptoms were collected from leaves and occasionally from fruits of melon $(\mathrm{Cucu}$ mis melo L.) cv. Honey Dew, squash ( $\mathrm{Cu}$ curbita maxima L.) cv. Camote, watermelon (Citrullus vulgaris L.) cv. Klondike, and zucchini (Cucurbita pepo L.) cv. Negro Chileno.

Samples showing the highest absorbance values in ELISA were used for particle purification and transmission to differential herbaceous hosts. Immunospecific electronic microscopy and protein Western blot were done on the purified particle, and specific reverse transcription-polymerase chain reaction (RT-PCR) was done on the purified RNA sample. Original samples were stored at $-70^{\circ} \mathrm{C}$ for several months, with no loss in ELISA reactivity.

Hosts specificity. Viral crude extracts were inoculated to the following hosts: Cucumis melo cv. Honey Dew, Cucurbita pepo, Chenopodium amaranticolor, $C$. quinoa, Pisum sativum, Nicotiana tabacum cv. Samsun, Datura stramonium, Phaseolus vulgaris cv. Pinto, and Luffa acutangula. The last five species are strainspecific hosts (6).

Ten plants of each species were mechanically inoculated using Carborundum and phosphate buffer, $10 \mathrm{mM}, \mathrm{pH} \mathrm{7.0,}$ supplemented with sodium metabisulfate, $10 \mathrm{mM}$, and diethyldithiocarbamic acid (DIECA), $10 \mathrm{mM}$. Isolates were propagated on Cucurbita pepo.

ELISA. ZYMV and WMV-II commercial polyclonal antibodies were purchased from SANOFI (Marnes La, Coquette, France), and double antibody sandwich (DAS)-ELISA was performed as described by Clark and Adams (5). Samples were ground 1:10 (wt/vol) in coating buffer (according to manufacturer's instructions) and incubated overnight at $4^{\circ} \mathrm{C}$. Antiserum incubations were done in the presence of phosphate-buffered saline with Tween (PBST) with $2 \%$ ovoalbumin for $3 \mathrm{~h}$ at $37^{\circ} \mathrm{C}$. Samples were considered positive if the absorbance at $\mathrm{OD}_{405 \mathrm{~nm}}$ was twice the average value of healthy controls.

Virus purification. Fresh tissue (300 g) was ground in $200 \mathrm{ml}$ of extraction solution (phosphate buffer $0.5 \mathrm{M}[\mathrm{pH}$ 7.5], $\mathrm{Na}_{2} \mathrm{SO}_{3} 0.02 \%$, EDTA $10 \mathrm{mM}$ ) and $24 \mathrm{ml}$ of $n$-butanol. This mixture was stirred for 2 $\mathrm{h}$ at $4^{\circ} \mathrm{C}$ and centrifuged at $10,000 \times g$ for $20 \mathrm{~min}$. To the supernatant, we added (final concentrations indicated): Triton X-100 $0.1 \%$ ( vol/vol), polyethyleneglycol (PEG) $8,0006 \%$ (wt/vol), and $\mathrm{NaCl} 100 \mathrm{mM}$. This mixture was stirred for $3 \mathrm{~h}$ at $4^{\circ} \mathrm{C}$ and centrifuged as above. The pellet was resuspended in 30 to $50 \mathrm{ml}$ of phosphate buffer $50 \mathrm{mM}$ (pH 8.2) plus EDTA $10 \mathrm{mM}$, then centrifuged at $10,000 \times g$ for $15 \mathrm{~min}$, and to the supernatant we added PEG 8,000 8\% (wt/vol, final concentration). The mix was stirred for $1 \mathrm{~h}$ at $4^{\circ} \mathrm{C}$ and then centrifuged at $35,000 \times g$ for $15 \mathrm{~min}$. The pellet was resuspended in $4 \mathrm{ml}$ of phosphate buffer 50 $\mathrm{mM}$ (pH 8.2) plus EDTA $10 \mathrm{mM}$, and this crude viral extract was separated by $\mathrm{CsCl}$ gradient at $30 \%(\mathrm{wt} / \mathrm{vol})$ (density $=1.23$ $\mathrm{g} / \mathrm{ml}$ ). These columns were centrifuged at $53,000 \mathrm{rpm}$ for $25 \mathrm{~h}$ at $20^{\circ} \mathrm{C}$ in a Beckman type $70 \mathrm{Ti}$ rotor. One-milliliter fractions, 
corresponding to viral bands, were collected, and the absorbance ratio 260/280 nm was determined.

To eliminate the $\mathrm{CsCl}$, each fraction was diluted 1:2 with phosphate buffer $50 \mathrm{mM}$ ( $\mathrm{pH}$ 8.2) plus EDTA $10 \mathrm{mM}$ and centrifuged at $12,000 \times g$ for $10 \mathrm{~min}$. PEG 8,000 $10 \%$ (wt/vol) and $\mathrm{NaCl} 100 \mathrm{mM}$ were added to the supernatant (final concentrations indicated), and this mix was stirred for $3 \mathrm{~h}$ and then centrifuged at $35,000 \times g$ for $20 \mathrm{~min}$. Finally, the pellet was resuspended in $100 \mu \mathrm{l}$ of phosphate buffer 50 $\mathrm{mM}(\mathrm{pH} \mathrm{8.2)}$ plus EDTA $10 \mathrm{mM}$.

Immunospecific electron microscopy (ISEM). Colodion and coal-coated 300mesh copper grids were floated $15 \mathrm{~min}$ on diluted 1:1,000 anti-ZYMV spots with phosphate buffer $0.05 \mathrm{M}, \mathrm{pH} 7.2$ (PB) and then washed with the same buffer. Aliquots of 1:10 diluted viral samples were added to the grids, incubated $15 \mathrm{~min}$, and washed with PB. Grids were again placed in antiserum diluted 1:50 in PB for 15 min, stained with $2 \%$ uranyl acetate, and observed for a contrasting reaction with a Zeiss EM 900 electron microscope.

Denaturing sodium dodecyl sulfatepolyacrylamide gel electrophoresis (SDSPAGE) and Western blot. SDS-PAGE (10\% polymer) and Western blot were carried out as described by Sambrook et al. (28) using polyclonal commercial antibodies (from SANOFI). For detection, $10 \mathrm{ml}$ of detection solution $\left(\mathrm{MgCl}_{2} 50 \mathrm{mM}, \mathrm{NaCl} 0.1\right.$ $\mathrm{M}$, and Tris- $\mathrm{HCl} 0.1 \mathrm{M}$ [pH 9.5]) supplemented with $45 \mu \mathrm{l}$ of NitroBlue Tetrazolium $(50 \mathrm{mg} / \mathrm{ml})$ and $35 \mu \mathrm{l}$ of X-Phosphate (50 $\mathrm{mg}$ of dimethylformamide per $\mathrm{ml}$ ) were added to each membrane. The reaction was stopped by adding $\mathrm{MgCl}_{2} 1 \mathrm{M}$.

Specific PCR amplification, cloning, and sequencing. Specific primers were designed using Oligo version 5.0 software. As templates, partial ZYMV sequences obtained from public databases were selected and analyzed (7,10,32). Designed primers ZYMV-forward (ZYMVfor): $5^{\prime}$ GCCGAGGTATGGTTTGCTTCG3' and ZYMV-reverse (ZYMVrev): 5'GCTTCCG ACAGGACTACGGCA3' (Integrated DNA Technologies, Coralville, IA) amplify a genomic region corresponding approximately to 395 bp of the $3^{\prime}$ region of the $\mathrm{CP}$ gene.

For the amplification reaction, viral ssRNA was purified using Trizol (Gibco BRL Life Technologies, Eggenstein, Germany) following the manufacturer's instructions. ssRNA was used as template for reverse transcription reaction using an oligo-dT $_{(14-17)}$ primer (Gibco-BRL) and SuperScript RT (Gibco-BRL) reverse transcriptase. The synthesized single strand cDNA was used as template for the specific PCR using Taq DNA polymerase (Gibco-BRL), ZYMVfor and ZYMVrev primers, with an amplification profile of 35 cycles of $1 \mathrm{~min}$ at $94^{\circ} \mathrm{C}, 1 \mathrm{~min}$ at $55^{\circ} \mathrm{C}$, and $1 \mathrm{~min}$ at $72^{\circ} \mathrm{C}$. The amplified fragment was purified using Wizard-PCR columns (Promega, Madison, WI) and then ligated into pGEM-T (Promega) plasmid. Positively recombinant clones were sequenced using an ABI-Prism 310 machine.

Statistical analysis of sequences. The nucleotide sequence corresponding to the local ZYMV was compared using BLAST search on the web site of the National Center for Biotechnology Information. Local ZYMV sequence and EMBL sequences derived from the matching process were selected and then compared using NALIGN alignment method of PCGene software (University of Geneva, Switzerland) to establish similarity, based on Myers and Miller (21). Sequence corresponding to 395 nucleotides from the Chilean isolate and 16 different ZYMV sources were computed for a distance matrix using DNAdist from Phylip package, version 3.6 (alpha) (University of Washington, Seattle), using the Kimura "2-parameter" method (13). The distance matrix was evaluated for successive clustering using the Neighbor-Joining component of the same package, based on Saitou and Nei (27).

\section{RESULTS}

Screening and host range studies. All of the collected samples from the central valleys of Chile exhibited viruslike symptoms. The zucchini samples cv. Negro Chileno showed yellow mosaic and severe leaf blistering, with distorted fruits forming prominent bumps. Melons cv. Honey dew exhibited vein clearing, yellow mosaic, and

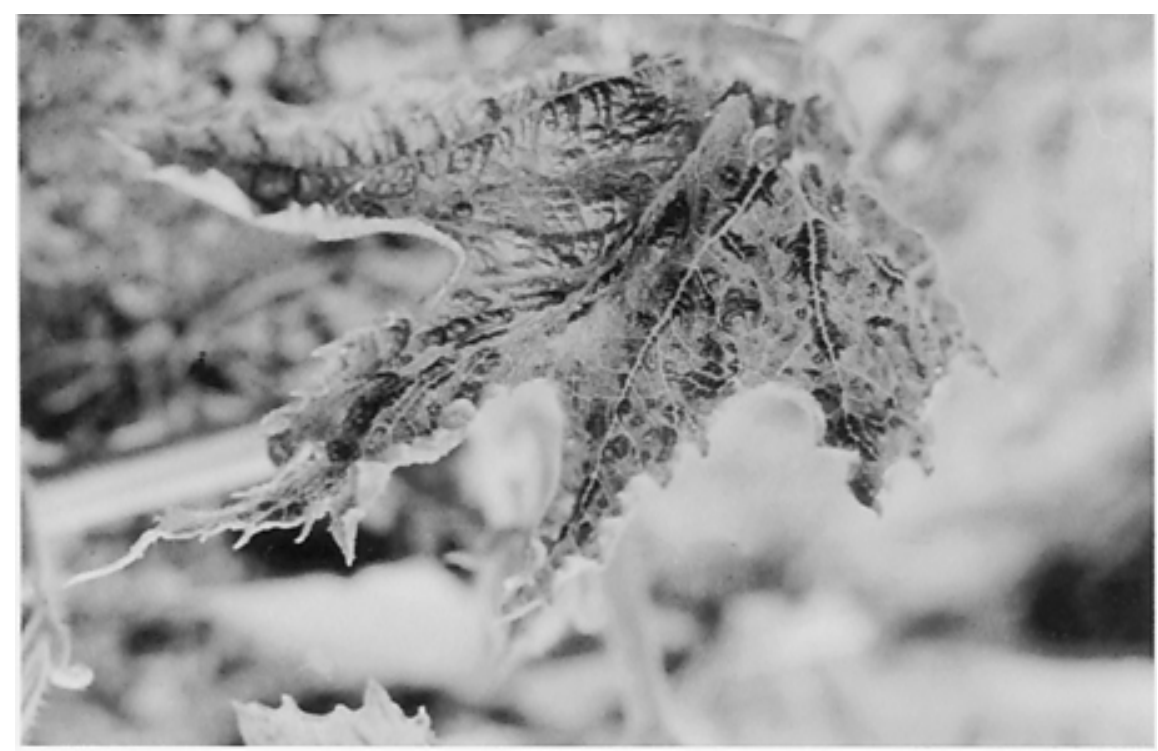

Fig. 1. Virus symptoms on Cucurbita pepo cv. Negro Chileno 2 weeks after mechanical inoculation with crude extracts of Zucchini yellow mosaic virus (ZYMV) enzyme-linked immunosorbent assay (ELISA)-positive samples. Leaves showed vein clearing, deformation, and lamina mosaic.

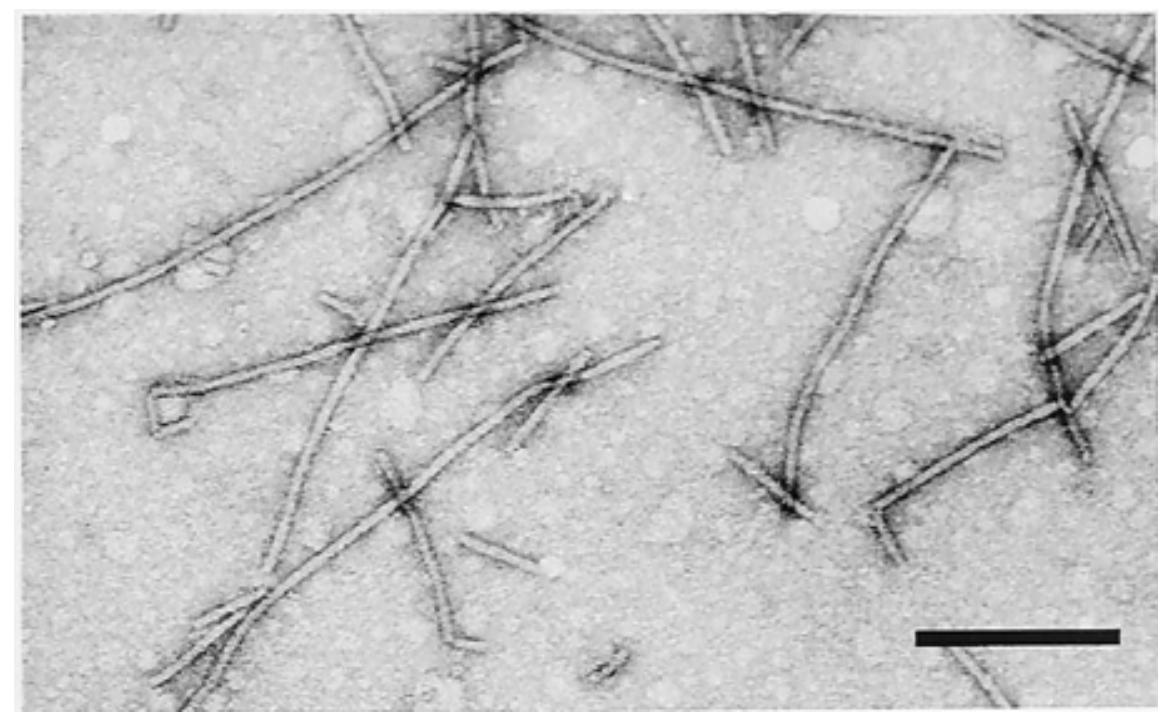

Fig. 2. Immunosorbent electron microscopy (ISEM) of purified potyviral particles decorated with polyclonal Zucchini yellow mosaic virus (ZYMV) antisera. Bar indicates $200 \mathrm{~nm}$. 
deformed leaves. Watermelon samples cv. Klondike showed mottle, mosaic, and leaf filimorphism. Symptoms in squash cv. Camote varied from mottle to severe mosaic.

ELISA detected only WMV-II in 26 melon, one zucchini, and five watermelon samples. One squash and two watermelon samples reacted only with ZYMV antibodies. One out of 10 squash samples reacted only with ZYMV antisera, seven samples only with WMV-II antisera, and two samples showed mixed infection of WMV-II and ZYMV. None of the samples were positive for CMV or Papaya ringspot virus (PRSV). Positive samples for ZYMV caused local chlorotic lesions in Chenopodium spp., mosaic in Luffa acutangula, Cucumis melo cv. Honey dew, and Cucurbita pepo 2 weeks postinoculation (Fig. 1).

Leaf samples from these symptomatic hosts gave absorbance values 3 to 15 times higher than control plants using polyclonal anti-ZYMV antibodies. Zucchini fruits showing prominent bumps gave the same positive reaction to these antibodies. No symptoms were observed on $D$. stramonium, N. tabacum cv. Samsun, $P$. vulgaris cv. Pinto, and P. sativum, and extracts from their leaves did not react with any of the antisera used in the ELISA.

WMV-II in crude extracts from infected samples incited mosaic symptoms in $\mathrm{Cu}$ curbita pepo and Cucumis melo cv. Honey dew, and local chlorotic lesions in Chenopodium amaranticolor and $C$. quinoa. Samples from all four species were positive in ELISA. No symptoms were observed on L. acutangula.

Virus purification and characterization. Greenhouse plants with the highest absorbance values determined in ELISA

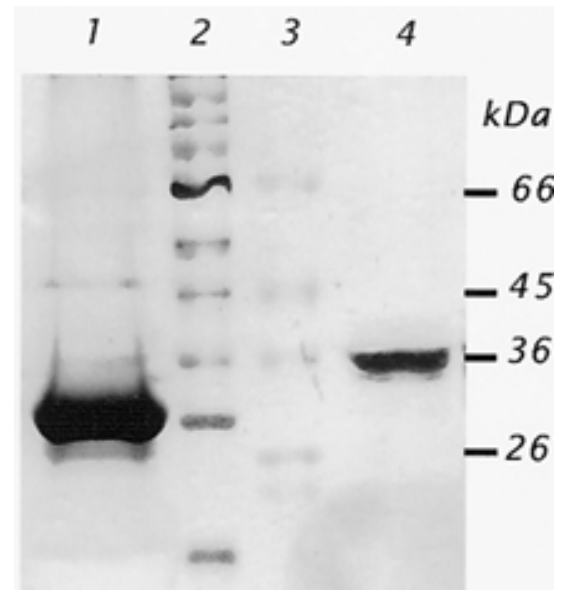

Fig. 3. Sodium dodecyl sulfate-polyacrylamide gel electrophoresis (SDS-PAGE) proteic pattern of Chilean isolate of Zucchini yellow mosaic virus (ZYMV) (lane 4). Lane 1, Watermelon mosaic virus type II; lane 2 , wide range molecular mass standard $(116,97,84,66,55,45$, 36,26 , and $20 \mathrm{kDa}$ ); lane 3, low molecular mass standard $(66,45,36$, and $29 \mathrm{kDa})$. Representative molecular masses are indicated (right). were chosen to purify the putative ZYMV. Electron microscopy analysis of the band from the $\mathrm{CsCl}$ gradient showed flexuous filamentous particles typical of the Potyviridae morphology (Fig. 2). Fifty particles ranged in length from 720 and $800 \mathrm{~nm}$, with $745 \mathrm{~nm}$ as modal value. The same kind of particle was observed in some crude sap samples (not shown). Immunodecoration showed that viral particles in these preparations reacted positively with the polyclonal anti-ZYMV antibodies. There was no decorative reaction when anti-WMV-II antibodies replaced the antiZYMV antibodies.

SDS-PAGE and Western blots using anti-ZYMV antibodies showed the presence of a main protein $36 \mathrm{kDa}$ (Fig. 3, lane 4) which was immunoreactive to the polyclonal antibodies (not shown). To confirm the identity of this virus, the viral genome was partially characterized. The DNA fragment, about $395 \mathrm{bp}$ in length, was cloned and sequenced (Fig. 4, accession no. bankit359290, AF 308732). FASTA comparison of this sequence confirmed the identity of the potyvirus isolated as ZYMV, matching with 17 different sequences described for this virus. Analysis by successive clustering of the 16 sequences with highest similarity permitted the design of an unrooted cluster phenogram. This tree showed that the Chilean isolate of ZYMV is part of a group composed of the Connecticut (10), California (32), Florida (26), and TW-NT1 (isolated in Taiwan, GenBank accession no. AF127933) strains (Fig. 5). Within this cluster, strains Connecticut and California (99.8\% similarity) formed a specific branch and showed 98.7 and $98.5 \%$ similarity to the Chilean isolate, respectively. The Florida and TW-NT1 strains were 97.5 and $95.2 \%$ similar to the Chilean isolate, respectively, being separated into another branch of the cluster. The cluster formed by the abovementioned strains, including the Chilean isolate, was about $94 \%$ similar to the cluster formed by the Hungarian strain (30), the cucumber strain CU (33), and the Japanese strain M (14) (Fig. 5).

\section{DISCUSSION}

We have confirmed, based on molecular analysis, the positive ELISA results obtained for ZYMV from a survey carried out in Chile (24), and that the Chilean isolate has characteristics similar to those of previously described isolates (6). Some strains of ZYMV have been reported to produce systemic infection without visible symptoms in $P$. sativum $(1,17)$, but the Chilean isolate did not infect this species. Absence of symptoms and negative ELISA titers on $P$. vulgaris cv. Pinto excluded the presence of the Lebanon strain in Chile, which has been described to systemically infect this host (17). The infection of $P$. vulgaris cv. Pinto is strain-specific and permitted us to discard the possibility that the Chilean ZYMV is close to the Lebanon strain (17), because the latter systemically infects this host. The absence of symptoms in $P$. vulgaris also has been described for some French and North American strains $(15,25)$.

Our SDS-PAGE pattern showed the presence of a protein of molecular mass 36 $\mathrm{kDa}$, the expected size for the $\mathrm{CP}$ from ZYMV previously reported (19) and distinct from the homologous protein from other cucurbit-infecting potyviruses such as WMV-II previously characterized in Chile (24) (Fig. 3, lane 1). This $36 \mathrm{kDa}$ protein was recognized by anti-ZYMV antibodies in Western blot assays, confirming the identity of the isolated viral particle as a potyvirus immunogenically related to ZYMV and confirming that ZYMV was present in Chile. Excluded ZYMV sequence corresponded to the strain Reunion Island (32), which was $77 \%$ similar with the Chilean ZYMV isolate. DNA distance analysis using Kimura's " 2 parameter," and later successive clustering by NeighborJoining method, showed the Chilean isolate grouping with some North American strains of the virus $(10,26,32)$ (Fig. 5). In addition to these strains, the Taiwanese strain TW-NT1 (AF 127933) was also included in the same cluster and was separate from the group constituted by different Taiwanese isolates. Even if the unrooted

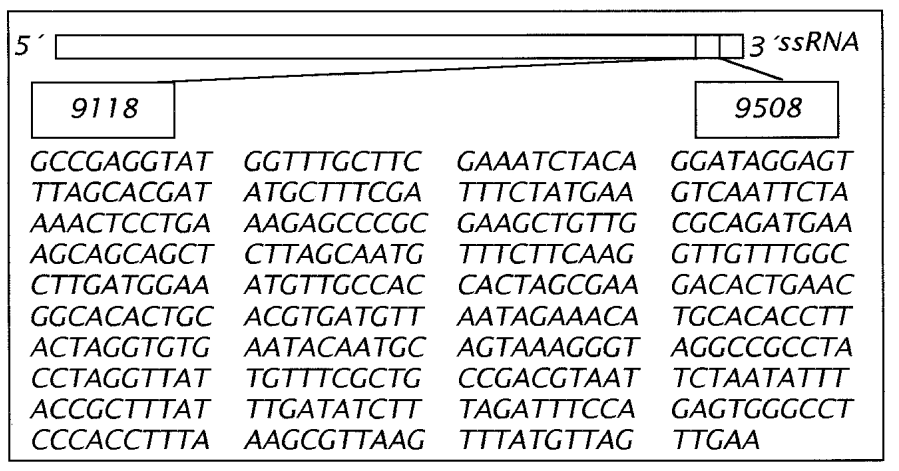

Fig. 4. Nucleotide sequence of $3^{\prime}$ end of the coat protein gene of the Chilean isolate of Zucchini yellow mosaic virus (ZYMV) (accession no. AF308732). Location and numbers are based on the complete sequence as described Wisler et al. (32). 
tree had no evolutionary meaning, these results determine a close relationship in terms of similarity between the North American strains and the Chilean isolate, in spite of the fact that they were separated into different branches (Fig. 5). In contrast, a slightly larger divergence from some Asian and European strains was seen. In this sense, it would be necessary to compare this sequence with others from the region (South America), as well as from other places such as the Caribbean region, Africa, or Oceania, to discuss the origin or displacement of the virus to these parts of the world. Work by Hernandez et al. (11), Vega et al. (31), and Gracia (8) have described ZYMV in terms of epidemics and serology in Brazil, Venezuela, and Argentina, respectively, but they did not report any genomic sequence data. Thomson et al. (29) described a 300-bp fragment corresponding to the $5^{\prime}$ extreme of the $\mathrm{CP}$ gene of Australian strains of ZYMV, but a comparison with our results is not feasible because we described the $3^{\prime}$ portion of the $\mathrm{CP}$ gene. Since natural plant resistance genes can be rapidly overcome by better adapted virus strains, knowledge of diversity and variability within a virus group is needed in order to develop virus-resistant cultivars. We are developing transgenic melon lines transformed with the $\mathrm{CP}$ gene of local isolates of WMV-II to confer resistance to this virus. This is of particular relevance now that we have confirmed the presence of WMV-II and ZYMV in Chile (24).

\section{ACKNOWLEDGMENTS}

We thank Victor Obreque for valuable help in the statistical analysis of the sequences. This work was partially supported by grants FONDECYTChile Numbers 1990207 and 1950017.

\section{LITERATURE CITED}

1. Antignus, Y., Raccah, B., Gal-On, A., and Cohen, S. 1989. Biological and serological characterization of zucchini yellow mosaic virus and watermelon mosaic virus-2 isolates in Israel. Phytoparasitica 17:289-298.

2. Auger, J., Escaffi, O., and Nome, F. 1974. Occurrence of watermelon mosaic virus 2 on cucurbits in Chile. Plant Dis. Rep. 58:599602.

3. Castle, S. J., Perring, T. M., Farrar, C. A., and Kishaba, A. N. 1992. Field and laboratory transmission of watermelon mosaic virus 2 and zucchini mosaic virus by various aphids species. Phytopathology 82:235-240.

4. Cho, J. J., Ullman, D. E., Wheatley, E., Holly, J., and Gonsalves, D. 1992. Commercialization of ZYMV cross protection for zucchini production in Hawaii. Phytopathology 82:1073.

5. Clark, M., and Adams, A. 1977. Characteristics of the microplate method of enzymelinked immunosorbent assay for the detection of plant viruses. J. Gen. Virol. 34:475-483.

6. Desbiez, C., and Lecoq, H. 1997. Zucchini

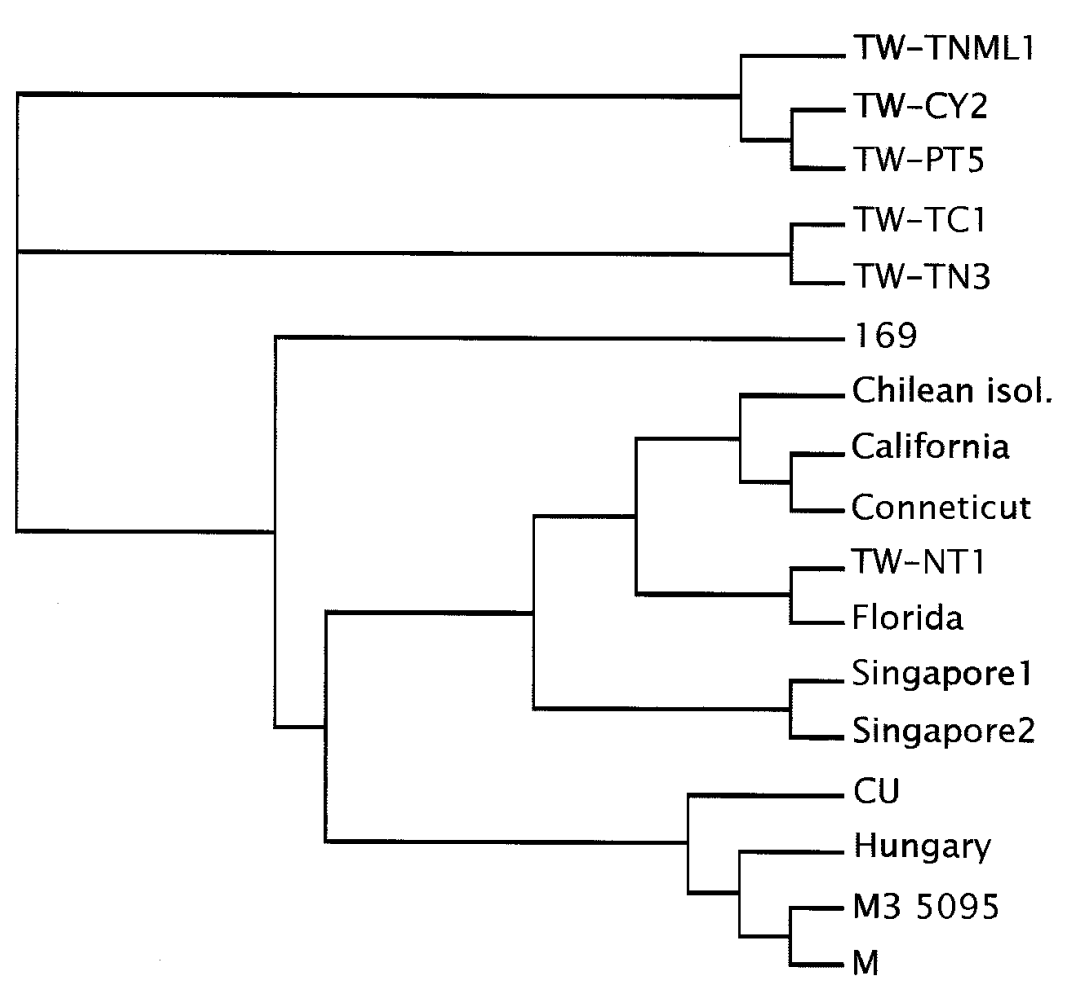

Fig. 5. Genetic distance phenogram of different strains and isolates of Zucchini yellow mosaic virus (ZYMV) based on $3^{\prime}$ end of genomic sequences. Nucleotide sequences of 395 bases corresponding to $3^{\prime}$ end of Chilean isolate and 16 different strains and isolates of ZYMV are represented in a distance matrix and then evaluated for successive cluster analysis using Neighbor-Joining method. TWTNML1 isolate (GenBank accession no. AF127932); TW-CY2 isolate (AF127930); TW-PT5 isolate (AF127934); TW-TC1 isolate (AF127931); TW-TN3 isolate (AF127929); 169 strain (14); California strain (32); Connecticut strain (10); TW-TN1 isolate (AF127933); Florida strain (26); Singapore1 strain (AF014811); Singapore2 strain (16); CU strain (33) (AF062518); Hungary, Hungarian strain, isolate 10 (30); M3 5095, CP sequence (7); M strain (14). yellow mosaic virus. Plant Pathol. 46:809829.

7. Gal-On, A., Antignus, Y., Rosner, A., and Raccah, B. 1990. Nucleotide sequence of the zucchini yellow mosaic virus capsid-encoding gene and its expression in Escherichia coli. Gene 87:273-277.

8. Gracia, O. 2000. First report of Zucchini yellow mosaic virus in Argentina. Plant Dis. 84:371.

9. Greber, R., McLean, G., and Grice, M. 1987. Zucchini yellow mosaic virus in three States of Australia. Aust. Plant Pathol. 16:19-21.

10. Grumet, R., and Fang, G. 1990. cDNA cloning and sequence analysis of the 3 '-terminal region of zucchini yellow mosaic virus RNA. J. Gen. Virol. 71:1619-1622.

11. Hernandez, J., Trujillo, G., Albarracín, F., and Zapata, F. 1989. Nueva enfermedad viral afectando cucurbitáceas en Venezuela. Fitopatol. Venez. 2:23.

12. Hseu, S., Wang, H., and Huang, C. 1985. Identification of a zucchini yellow mosaic virus strain from Cucumis sativus. J. Agric. Res. China 34:87-95.

13. Kimura, M. 1980. A simple method for estimating evolutionary rates of base substitutions through comparative studies of nucleotide sequences. J. Mol. Evol. 16:111-120.

14. Kundu, A., Ohshima, K., and Sako, N. 1997. Nucleotide sequences of the coat protein genes of two Japanese zucchini yellow mosaic virus isolates. Acta Virol. 41:297-301.

15. Lecoq, H., Pitrat, M., and Clément, M. 1981. Identification et caractérisation d'un potyvirus provoquant la maladie du rabougrissement jaune du melon. Agronomie 1:827-834.

16. Lee, S., Wu, M., and Wong, S. 1993. Nucleotide sequence of a Singapore isolate of zucchini yellow mosaic virus coat protein gene revealed an altered DAG motif. Virus Genes 7:381-387

17. Lesemann, D., Makkouk, K., Koenig, R., and Natafji Samman, E. 1983. Natural infections of cucumbers by zucchini yellow mosaic virus in Lebanon. Phytopathol. Z. 108:304-313.

18. Lisa, V., Boccardo, G., D'Agostino, G., Dellavalle, G., and D'Aquilio, M. 1981. Characterization of a potyvirus that causes zucchini yellow mosaic. Phytopathology 71:667-672.

19. Lisa, V., and Lecoq, H. 1984. Zucchini yellow mosaic virus. CMI/AAB Description of Plant Viruses No. 282, Kew, Surrey, England.

20. Makkouk, K., and Menassa, R. 1986. Effects of mineral oil spray on aphid transmission of zucchini yellow mosaic virus to cucumbers. Arab. J. Plant Prot. 3:18-23.

21. Myers, E., and Miller, W. 1988. Optimal alignments in linear space. Comput. Appl. Biosci. 4:11-17.

22. Nameth, S., Dodds, J., Paulus, A., and Kishaba, A. 1985. Zucchini yellow mosaic virus associated with severe diseases of melon and watermelon in southeastern California desert valleys. Plant Dis. 69:785-788.

23. Nome, F., and Docampo, D. 1968. An additional list of plant pathogens not previously reported in Chile. Plant Dis. Rep. 52:703704.

24. Prieto, H., Bruna, A., Hinrichsen, P., and Muñoz, C. 1999. Identificación y caracterización de aislamientos chilenos del virus del mosaico de la sandía tipo II. Agric. Téc. (Chile) 58:247-257.

25. Provvidenti, R., Gonsalves, D., and Humaydan, H. S. 1984. Occurrence of zucchini yellow mosaic virus in cucurbits from Connecticut, New York, Florida, and California. Plant Dis. 68:443-446.

26. Quemada, H., Siu, L., Siemeniak, D., Gonsalves, D., and Slightom, J. 1990. Watermelon mosaic virus II and zucchini yellow mosaic virus: Cloning of 3'-terminal regions, nucleotide 
sequences, and phylogenic comparisons. J. Gen. Virol. 71:1451-1460.

27. Saitou, N., and Nei, M. 1987. The neighborjoining method: A new method for reconstructing phylogenetic trees. Mol. Biol. Evol. 4:406-425.

28. Sambrook, J., Fritsch, E., and Maniatis, T. 1989. Molecular Cloning: A Laboratory Manual. 2nd ed. Cold Spring Harbor Laboratory, Cold Spring Harbor, NY.

29. Thomson, K., Dietzgen, R., Gibbs, A., Tang,
Y., Liesack, W., Teakle, D., and Stackebrandt, E. 1995. Identification of Zucchini yellow mosaic potyvirus and analysis of sequence variability. J. Virol. Methods 55:83-96.

30. Tobias, I., Palkovics, L., and Balazs, E. 1998. Characterisation of Hungarian strain of zucchini yellow mosaic potyvirus causing severe damage on cucurbit plants. Novenyvedelem 34:613-616.

31. Vega, J., Rezende, J., Yuki, V., and Nagai, H. 1992. Constataciao do virus do mosaico ama- relo da aborinha-de-moita ("zucchini yellow mosaic virus") no Brasil, atravésde MEIAD e ELISA. Fitopatol. Bras. 17:118.

32. Wisler, G., Purcifull, D., and Hiebert, E. 1995. Characterization of the $\mathrm{P} 1$ protein and coding region of the zucchini yellow mosaic virus. $\mathbf{J}$. Gen. Virol. 76:37-45.

33. Yoon, J., and Choi, J. 1998. Nucleotide sequence of $3^{\prime}$ terminal region of zucchini yellow mosaic virus (cucumber isolate) RNA Hangug Sigmur Byenrihag Hoiji 14:23-27. 